\title{
Cardiac resynchronization therapy in Romania - results from the European Society of Cardiology CRT Survey II
}

loana Sus', Radu Vatasescu², Calin Siliste ${ }^{3}$, Alexandru Deutsch ${ }^{4}$, Dragos Cozma ${ }^{5}$, Radu Ciudin ${ }^{6}$, Sorin Micu Horia Rosianu ${ }^{8}$, Cristian Statescu, Gabriel Gusetu' ${ }^{10}$, Kenneth Dickstein ${ }^{11}$, Camilla Normand ${ }^{11,12}$, Cecilia Linde ${ }^{13}$, Dan Dobreanu'

\begin{abstract}
Objectives - The European Cardiac Resynchronization Therapy Survey II is the second CRT survey of the Heart Failure Association and European Heart Rhythm Association designed to observe implantation and follow-up practices across European countries. These data allow, for the first time, a valuable insight on CRT implantation strategies for Romanian patients. Methods - A total of 214 patients undergoing CRT-P/CRT-D implantations in 7 Romanian implantation centers were included in the survey. A one-time online case report form including data on implantation indication and procedure was completed for each implantation attempt. Results - Romanian patients were younger than the other European patients $(p<0.00 \mathrm{I})$, had more severe symptoms of heart failure, lower ejection fraction and wider QRS complexes. More than half of the patients had non-ischemic cardiomyopathy. Most of the patients were in sinus rhythm, with a median intrinsic QRS duration of $163 \pm 24$ ms. Echocardiography was the imaging method most often used and the median left ventricular ejection fraction was $24.9 \pm 8 \%$. In comparison with other European countries, CRT-D devices and multipolar ventricular leads were more rarely implanted $(\mathrm{p}<0.00 \mathrm{I})$. Conclusions - In Romania indications regarding CRT implantation follow the most recent ESC guidelines, but the ratio of CRT-D devices in Romania is lower than in the other European countries and patients with more severe heart failure receive CRT. CRT should be considered earlier in heart failure patients in order to improve outcome.
\end{abstract}

Keywords: heart failure, cardiac resynchronization therapy.

Rezumat: Obiective - European Cardiac Resynchronization Therapy Survey II este al doilea sondaj privind terapia de resincronizare cardiacă (CRT) al Heart Failure Association și al European Heart Rhythm Association, realizat cu scopul de a evalua practicile de implant și urmărire a pacienților în țările europene. Aceste date permit, pentru prima dată, o imagine în detaliu asupra strategiilor de implant CRT la pacienții din România. Metode - În studiu au fost incluși 214 pacienți cărora li s-a implantat un CRT-P/CRT-D în 7 centre de implant din România. Pentru fiecare tentativă de implant s-a completat online un formular incluzând date despre indicație și procedură. Rezultate - Pacienții cu CRT din România au fost mai tineri decât restul pacienților din Europa $(\mathrm{p}<0,00 \mathrm{I})$, au avut simptome de insuficiență cardiacă mai severe, fracție de ejecție mai scăzută și o durată mai crescută a complexului QRS. Mai mult de jumătate dintre pacienți au avut cardiomiopatie non-ischemică. Majoritatea pacienților au fost în ritm sinusal și au avut o durată medie a complexului QRS de $163 \pm 24$ ms. Metoda imagistică cel mai frecvent folosită a fost ecocardiografia, iar fracția de ejecție medie a ventriculului stâng a fost $24,9 \pm 8 \%$. În comparație cu celelalte țări europene, în România au fost implantate mai puține dispozitive de tip CRT-D și sonde ventriculare multipolare $(p<0,00 I)$. Concluzie - În România indicațiile privind terapia de resincronizare cardiacă urmează recomandările celor mai recente ghiduri ale ESC, dar proporția dispozitivelor de tip CRT-D în România este mai mică decât în celelalte țări Europene și pacienți cu insuficiență cardiacă mai severă beneficiază de CRT. CRT ar trebui să fie luată în considerare mai precoce la pacienții cu insuficiență cardiacă pentru ameliorarea răspunsului.

Cuvinte cheie: insuficiență cardiacă, terapie de resincronizare cardiacă.

\footnotetext{
' Institute for Cardiovascular Disease and Transplant, Tirgu Mures, Romania

${ }^{2}$ Clinical Hospital Floreasca, Bucharest, Romania

${ }^{3}$ University Clinical Hospital, Bucharest, Romania

${ }^{4}$ Colentina Clinical Hospital, Bucharest, Romania

${ }^{5}$ Heart Institute, Timisoara, Romania

${ }^{6}$ „Prof. Dr. C.C. Iliescu” Institute for Cardiovascular Diseases, Bucharest, Romania

${ }^{7}$ ICCO Clinics, Brasov, Romania

${ }^{8}$ Heart Institute, Cluj-Napoca, Romania
}

\footnotetext{
${ }^{9}$ Heart Institute, lasi, Romania

${ }^{10}$ Clinical Hospital of Rehabilitation, Cluj Napoca, Romania

" Division of Cardiology, Stavanger University Hospital, Stavanger, Norway

${ }^{12}$ Institute of Internal Medicine, University of Bergen, Norway

${ }^{13}$ Heart and Vascular Theme, Karolinska University Hospital and Karolinska Institute, Stockholm, Sweden
}

\section{$\checkmark$ Contact address:}

loana Sus, 50, Gheorghe Marinescu Street, 540139, Tirgu Mures, Romania.

E-mail: susioana@yahoo.com 


\section{BACKGROUND}

Cardiac resynchronization therapy (CRT) is an important therapeutic option for patients with symptomatic heart failure, a wide QRS complex, left ventricular ejection fraction below $35 \%$ receiving optimal medical treatment'. The 2013 European Society of Cardiology (ESC) guideline for Pacing and Cardiac Resynchronization Therapy ${ }^{2}$ and 2016 ESC Acute and Chronic Heart Failure guideline' provide a class I recommendation for CRT and the technology is continuously evolving improving the outcome in patients receiving CRT. However, there are important differences regarding implantation choices among the European countries ${ }^{3}$. The European Cardiac Resynchronization Therapy Survey II is the second CRT survey from the Heart Failure Association and European Heart Rhythm Association of European Society of Cardiology designed to observe implantation and follow-up practices across European countries. $^{3}$ The first CRT survey in 2009 revealed a high percentage of off-label implantations, 19\% of the patients had a QRS complex duration below $130 \mathrm{~ms}$ and $22 \%$ were in NYHA functional class I and II ${ }^{4}$. Since the publication of CRT Survey I, guidelines have been updated and indications which were considered off-label are now class I indications due to results in recent trials such as Resynchronization reVErses Remodeling in Systolic left vEntricular dysfunction trial (REVERSE) ${ }^{5}$, Multicenter Automatic Defibrillator Implantation Trial with Cardiac Resynchronization Therapy (MADIT-CRT) ${ }^{6}$ and Resynchronization-Defibrilation for Ambulatory Heart Failure Trial (RAFT) ${ }^{7}$.

For Romania, this is the first data collection and analysis regarding CRT implantation practice. These data provide a valuable insight on CRT implantation strategies for Romanian patients.

\section{METHODS}

\section{Study design}

The European Cardiac Resynchronization Therapy Survey II is an international snapshot survey initiated by Heart Failure Association and European Heart Rhythm Association, including patients from 42 ESC countries undergoing CRT implantation ${ }^{3}$. CRT implanting centers from the 47 ESC countries detailed in EHRA White Book 2013 were invited to participate in the survey.

\section{Study population}

Consecutive patients undergoing de novo CRT-P/ CRT-D implantations or upgrade from permanent implantable cardiac defibrillator or pacemaker were included between October 2015 and December 2016. A one-time online case report form was completed for each implantation attempt, regardless of the procedural success. Collected data included information about demographics, heart failure etiology, past medical history and major comorbidities, pre-implantation electrocardiography, clinical indication for CRT, details regarding the implantation procedure comprising LV lead position, peri-procedural complications, device programming, treatment and follow-up plan at discharge. No informed consent was obtained for the survey as the eCRT was completely anonymized. The study protocol was approved by the Romanian Society of Cardiology and local ethics committees.

\section{Statistical analysis}

Data analysis was performed by Institut fur Herzinfarktforschung in Ludwigshafen, Germany, appointed by the organizing associations. Data is presented as percentages and numbers or mean and standard deviation, as appropriate. For comparison, Chi-squared or Mann-Whitney-Wilcoxon tests were used accordingly.

\section{RESULTS}

The registry included a total of I I.088 patients from 288 implantation centers in 42 countries. In Romania, 7 implantation centers responded to the survey and 214 patients were included, constituting $1.93 \%$ of the survey population. In Romania these 214 patients constituted $57 \%$ of all CRT implantations performed in the time period of the Survey, making the data very representative for national CRT implantation patterns. These patients underwent 216 implantation attempts with 212 successful attempts (99.1\%).

Romanian implantation centers were similar to the other European centers regarding the number of dedicated electrophysiological labs ( $1.3 \pm 0.5$ vs. I. $3 \pm 0.9$, $p=0.77)$, electrophysiologists $(2 \pm l$ vs. $3 \pm 2, p=0.59)$ and heart failure specialists $(I \pm 2$ vs. $I \pm 2, p=0.38)$. The reported number of CRT implantations per year was smaller in Romanian implantation centers compared with the total cohort. ( $38 \pm 24$ vs. $73 \pm 61, p=0.09)$, but statistically significant only for CRT-D devices $(20 \pm 16$ vs. $50 \pm 46, p=0.02$ ).

\section{Demographics and history}

Romanian patients were younger than the other European patients $(65.2 \pm \mathrm{I}$ I.I vs $68.6 \pm 10.8$ years, $\mathrm{p}<0.00 \mathrm{I})$, with the majority below the age of 65 years of age (43.9\%). A smaller proportion of patients were abo- 
ve 75 years of age compared to all other countries ( $21.0 \%$ vs. $32.2 \%$ ) (Table I). Although male gender was more prevalent over-all, a higher percentage of female patients were implanted in Romania than in the other European countries ( $32.2 \%$ vs. $24.1 \%, p=0.006)$.

The etiology of heart failure was in more than half of the patients non-ischemic (63.6\%). Regarding major comorbidities, patients undergoing CRT implantation in Romania had lower prevalence of previous myocardial infarction, prior revascularization, hypertension or atrial fibrillation, but more frequently had valvular heart disease.

Among the 214 patients, 48 (22.4\%) had a previous device implantation, most often a permanent pacemaker (32 patients, 66.7\%). A significantly lower number of Romanian patients had a previous ICD implanted in comparison with all other countries ( $16.7 \%$ vs. $31.9 \%$, $p=0.02$ ).

\section{Pre-implant evaluation}

Before CRT implantation, Romanian patients had more severe symptoms according to NYHA functional class than other European patients (Figure I). The majority of them were in NYHA functional class III
(57.5\%) and IV (17\%), and more Romanian patients had been hospitalized for heart failure during the past year $(65.9 \%$ vs. $46.1 \%, \mathrm{p}<0.00 \mathrm{I})$ as a sign of worse heart failure condition in Romanian patients. They also had more commonly mitral regurgitation which was also of greater severity in Romanian patients.

Most of the Romanian patients were in sinus rhythm, $78.4 \%$, and a smaller proportion; $17.4 \%$ were in atrial fibrillation at time of implantation (Table 2). The median heart rate was $72 \pm 13 \mathrm{bpm}$. The median PR interval was $179 \pm 52 \mathrm{~ms}$, and intrinsic QRS duration was $163 \pm 24 \mathrm{~ms}$. Left bundle branch block morphology was dominant (83.1\%), followed by right bundle branch block $(5.6 \%)$, and $2.8 \%$ of the patients had a normal QRS morphology. Twenty-four (II.3\%) of the Romanian patients were pacemaker dependent, with a median paced QRS duration of $165 \pm 23 \mathrm{~ms}$. Fewer patients with narrow QRS complex $(<120 \mathrm{~ms})$ underwent CRT implantation in Romania compared with other countries (3.6\% vs. $7.5 \%$ ) (Table 2$)$, and $6.2 \%$ of Romanian patients compared to $12.9 \%$ in all other countries had a QRS complex duration below 130 ms which suggests better guidelines adherence in Romania.

\begin{tabular}{|c|c|c|c|c|}
\hline & $\begin{array}{c}\text { Romania } \\
(n=2 \mid 4)\end{array}$ & $\begin{array}{l}\text { All other countries } \\
\qquad(n=\mid 0874)\end{array}$ & P-value & OR $(95 \% \mathrm{CI})$ \\
\hline Age & $65.2 \pm 11.1$ & $68.6 \pm 10.8$ & $<0.001$ & \\
\hline Women & $69(32.3 \%)$ & $2617 / 10838(24.1 \%)$ & 0.006 & \\
\hline \multicolumn{5}{|l|}{ History and comorbidities } \\
\hline Myocardial infarction & $62(29.0 \%)$ & $3895 / 107 / 2(36.4 \%)$ & 0.025 & $0.71(0.53-0.96)$ \\
\hline Prior revascularization (PCI/CABG) & $50(23.4 \%)$ & $4195 / 107 / 0(39.2 \%)$ & $<0.001$ & $0.47(0.34-0.65)$ \\
\hline Hypertension & $117(54.7 \%)$ & $6845 / 10686(64.1 \%)$ & 0.004 & $0.68(0.52-0.89)$ \\
\hline Atrial fibrillation & $77(36.0 \%)$ & $4382 / 10706$ (40.9\%) & 0.144 & \\
\hline Valvular heart disease & 87 (40.7\%) & $288 \mathrm{I} / 10706(26.9 \%)$ & $<0.001$ & $1.86(1.4 I-2.45)$ \\
\hline COPD & $12(5.6 \%)$ & $1303 / 10708(12.2 \%)$ & 0.003 & $0.43(0.24-0.77)$ \\
\hline Diabetes mellitus & $57(26.6 \%)$ & $3371 / 10707$ (3I.5\%) & 0.130 & \\
\hline Anemia & $25(11.7 \%)$ & $1615 / 10702(15.1 \%)$ & 0.167 & \\
\hline CKD & $55(25.7 \%)$ & $3340 / 10693(31.2 \%)$ & 0.083 & \\
\hline Obesity & $71 / 213(33.3 \%)$ & $3091 / 10261$ (29.4\%) & & \\
\hline HF hospitalizations during past year & $14|/ 2| 4(65.9 \%)$ & $4937 / 10703(46.1 \%)$ & 0.00001 & \\
\hline \multicolumn{5}{|c|}{ Medical treatment at discharge after CRT implantation } \\
\hline Loop diuretic & $183 / 210(87.1 \%)$ & $8438 / 10425$ (80.9\%) & 0.023 & \\
\hline ACE inhibitor/ARB & $|82 / 2| I(86.3 \%)$ & $898 \mathrm{I} / 10392(86.4 \%)$ & 0.944 & \\
\hline MRA & $176 / 211(83.4 \%)$ & $6506 / 10362(62.8 \%)$ & $<0.001$ & \\
\hline Betablocker & $187 / 2 \mid I(88.6 \%)$ & $9285 / 10437(89.0 \%)$ & 0.877 & \\
\hline Ivabradine & $13 / 208(6.3 \%)$ & $580 / 1033(55.6 \%)$ & 0.692 & \\
\hline Digoxin & $48 / 209(23.0 \%)$ & $1052 / 10335(10.2 \%)$ & $<0.001$ & \\
\hline Calcium channel blocker & $6 / 209(2.9 \%)$ & $940 / 10322(9.1 \%)$ & 0.001 & \\
\hline Amiodarone & $67 / 209(32.1 \%)$ & $1758 / 10338(17.0 \%)$ & $<0.001$ & \\
\hline
\end{tabular}




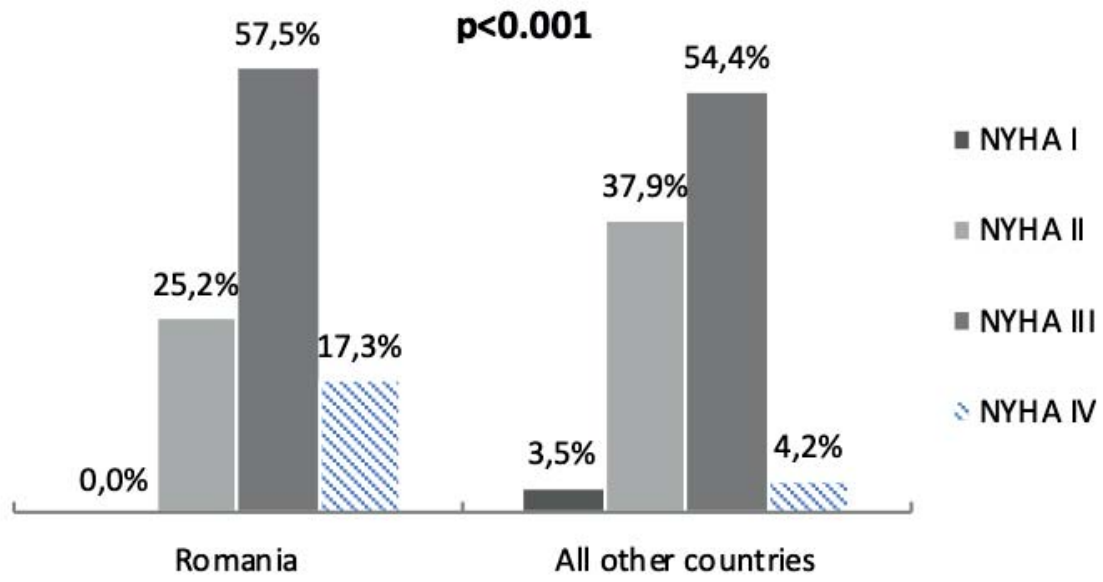

Figure I. Pre-implantation New York Heart Association class in Romanian and European patients. Data available for 214 and I0643 patients, respectively.

Echocardiography was the imaging method most frequently used for evaluating left ventricular function ( $97.2 \%$ of the patients), followed by cardiac magnetic resonance (4.2\%). Romanian patients had larger left ventricular end diastolic diameters and smaller ejection fractions. Moderate and severe mitral regurgitati- on were present more often in Romania in $37.7 \%$ and $22.5 \%$ of patients, respectively reflecting the more severe HF disease state of Romanian patients (Table 2).

Amongst indications for CRT (bearing in mind that more than one could be given in the CRF) heart failure with wide $\mathrm{QRS}$ complex was considered the indication

\begin{tabular}{|c|c|c|c|}
\hline & $\begin{array}{c}\text { Romania } \\
(n=2 \mid 3)\end{array}$ & $\begin{array}{l}\text { All other countries } \\
(n=10874)\end{array}$ & P-value \\
\hline \multicolumn{4}{|l|}{ Electrocardiography } \\
\hline Heart rate (bpm) & $72 \pm 16$ & $72 \pm 17$ & 0.76 \\
\hline Sinus rhythm & 167 (78.4\%) & $7329 / 10623(69.0 \%)$ & \\
\hline Atrial fibrillation & $37(17.4 \%)$ & $274 I / I 0623(25.8 \%)$ & \\
\hline PR interval (ms) & $179 \pm 52$ & $189 \pm 50$ & $<0.001$ \\
\hline Intrinsic QRS duration & $163 \pm 24$ & $157 \pm 27$ & 0.001 \\
\hline Intrinsic QRS duration $<120 \mathrm{~ms}$ & $7 / 193(3.6 \%)$ & $704 / 9342(7.5 \%)$ & \\
\hline Pacemaker dependent & $24(11.3 \%)$ & $1487 / 10539(14.1 \%)$ & 0.237 \\
\hline Paced QRS duration & $165 \pm 23$ & $|8| \pm 3 \mid$ & 0.003 \\
\hline \multicolumn{4}{|l|}{ QRS morphology } \\
\hline Normal & $6 / 213(2.8 \%)$ & $773 / 10587$ (7.3\%) & 0.012 \\
\hline LBBB & $177 / 213(83.1 \%)$ & $7684 / 10587(72.6 \%)$ & $<0.001$ \\
\hline RBBB & $12 / 213(5.6 \%)$ & $698 / 10587(6.6 \%)$ & 0.575 \\
\hline \multicolumn{4}{|l|}{ Echocardiography } \\
\hline LEVF* & $24.9 \pm 8.0 \%$ & $28.5 \pm 8.1 \%$ & $<0.001$ \\
\hline$\geq 50 \%$ & $0 / 213(0.0 \%)$ & $195 / 10592(1.8 \%)$ & \\
\hline$\geq 35 \%$ & $15 / 213(7.0 \%)$ & $1385 / 10592(13.1)$ & \\
\hline $25-35 \%$ & $96 / 213(45.1 \%)$ & $6330 / 10592(59.8 \%)$ & \\
\hline$<25 \%$ & $102 / 213(47.9 \%)$ & $2877 / 10592(27.2 \%)$ & \\
\hline LVEDD & $65.5 \pm 8.5$ & $63.5 \pm 9.2$ & 0.011 \\
\hline Mitral regurgitation & & & $<0.001$ \\
\hline Mild & $61 / 191(31.9 \%)$ & $4583 / 9809(46.7 \%)$ & \\
\hline Moderate & $72 / 191$ (37.7 \%) & $2574 / 9809$ (26.2 \%) & \\
\hline Severe & $43 / 191$ (22.5\%) & $647 / 9809(6.6 \%)$ & \\
\hline
\end{tabular}


for CRT in $72.3 \%$ of patients, in contrast with $59.7 \%$ in other countries. This was followed by evidence of mechanical dyssynchrony in $40.4 \%$ of Romanian patients and left ventricle dysfunction combined with an indication for ICD in $48.2 \%$ of the patients implanted in the other centers (Figure 2).

\section{CRT-implantation procedure}

The 2I4 patients underwent a number of 216 CRT implantation attempts, with a success rate of $98.6 \%$, similar to the European cohort. The three unsuccessful attempts were all due to failure to place the LV lead. The 212 successful implantations resulted in an almost equal number of CRT-P (50.5\%) and CRT-D (49.5\%) devices, in contrast with the other countries where CRT-D devices were more frequently used $(70.2 \%$, $\mathrm{P}<0.00$ I).

In Romania, $97.6 \%$ of implantations were performed by electrophysiologists (in contrast with the other countries, $76.6 \%$ ) and the remaining ones by cardiac surgeons, whereas in Europe $12.6 \%$ of devices were implanted by invasive cardiologists and $5.1 \%$ by heart failure specialists. A significantly higher number of procedures were performed in catheterization laboratories $(40.1 \%)$, followed by device implantation laboratories $(29.2 \%)$ and dedicated electrophysiology laboratories (29.2\%) in Romania. In contrast, in Europe the majority of devices were implanted either in device implantation $(33.6 \%)$ or dedicated electrophysiology laboratories (30.7\%). In Romania, procedures lasted longer (I I3.6 $\pm 37.2 \mathrm{~min}$ vs. $99.5 \pm 46.4 \mathrm{~min}, \mathrm{p}<0.00$ I), but there was no difference in fluoroscopy time, with a median of 17 min. Right ventricular lead was most often implanted first (74.4\%), more frequently in a septal position in Romanian patients (64.7\%), whereas in the other countries the apical position was preferred $(61.8 \%)$.

For LV lead implantation, almost all Romanian patients had a coronary venogram $(95.3 \%$ vs. $91.4 \%$, $\mathrm{p}=0.048$ ).

Left ventricular (LV) lead was placed epicardially in $10 \%$ of the Romanian patients, similar to the global results (9.2\%). Bipolar leads were most frequently used in Romanian patients ( $80.1 \%$ vs. $41.5 \%$, $\mathrm{p}<0.00 \mathrm{I}$ ), with a low percentage of multipolar leads (19.4\% vs. $57.8 \%)$. LV lead position was usually evaluated with biplane $x$-ray projections (92.6\%) and optimized based on the measured electrical delay (time interval from onset of $Q$ wave to LV EGM) in most of the Romanian patients, while in the other countries the paced QRS duration was the elected criteria for LV lead position optimization.

The incidence of periprocedural complications was almost double in Romania versus the other countries (9.3\% vs. $5.5 \%, p=0.016)$, bleeding and coronary sinus dissection being the most common complications (35\% of complications each), followed by pneumothorax and pericardial tamponade ( $10 \%$ of complications each) (Table 3).

\section{Outcomes}

Atrioventricular (AV) and interventricular (VV) delay programming was performed in the majority of patients prior to discharge, more often in Romanian pati-

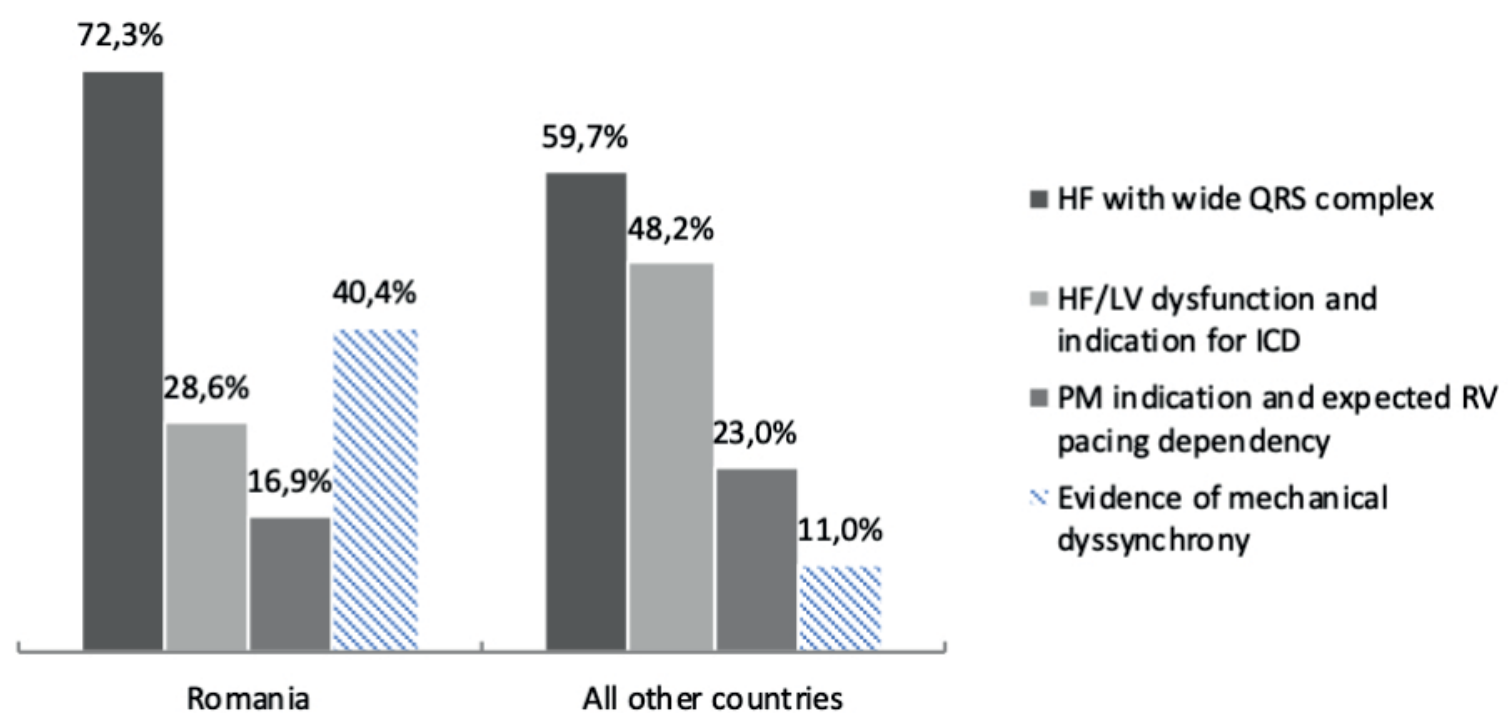

Figure 2. Indications for CRT in Romanian and European patients. HF - heart failure; LV - left ventricle; PM - pacemaker. 


\begin{tabular}{l}
$\begin{array}{l}\text { Table 3. Comparison of periprocedural complications } \\
\text { in patients undergoing CRT implantation in Romania } \\
\text { and Europe }\end{array}$ \\
\hline
\end{tabular}

ents compared with the total cohort ( $85.0 \%$ vs. $57.3 \%$, $\mathrm{p}<0.00 \mathrm{I}$ and $67.1 \%$ vs. $56.1 \%, \mathrm{p}=0.00 \mathrm{I}$, respectively). While $37.1 \%$ of the European patients had a devicebased software optimization for $\mathrm{AV}$ and $\mathrm{VV}$ delays, in Romania this was the option for only one patient.

Post-CRT, a shortening of average $32 \pm 24 \mathrm{~ms}$ of the duration of QRS complex was obtained, this shortening was more pronounced in the Romanian patients (all other countries $20 \pm 30 \mathrm{~ms}, \mathrm{p}<0.00 \mathrm{I}$ ) and the average $Q R S$ duration was $132 \pm 16 \mathrm{~ms}$, with $48.8 \%$ of the patients having paced QRS duration between I 30 and 150 ms.

All patients were discharged alive, after an average length of hospital stay of $7 \pm 5.7$ days. The incidence of major adverse events during hospitalization after procedure was low (5.6\%), predominantly represented by arrhythmias (2.8\%), followed by worsening renal function (1.9\%). Five patients experienced lead dislocation or displacement $(2.8 \%)$, this related to the LV lead in $80 \%$ of the cases. No peri-procedural infections were reported. More than $80 \%$ of patients were discharged on guideline-recommended heart failure medication, including betablocker, angiotensin converting enzyme inhibitor and mineralocorticoid receptor antagonist (Table I).

The follow-up strategy in Romania was very different from all other countries, as all patients were scheduled for follow-up in the implanting center, whereas in the other countries $8.2 \%$ were scheduled to be followed in other hospital, $10.6 \%$ in CRT/pacemaker clinics and $2.6 \%$ in heart failure management clinic (all $\mathrm{P}<0.05)$.

\section{DISCUSSION}

The European Cardiac Resynchronization Therapy Survey II was designed to evaluate actual practices regarding CRT across European countries, to identify variations in patient selection, procedural options and CRT outcome in a real-life population ${ }^{3}$. In Romania, the number of implanted CRT units increased four-fold, from a total of 99 to 421 , between 2008 and $2016^{8,9}$. The increase may not only be due to extension of implantation indications to patients in NYHA functional class II in the 20I3 ESC Guidelines for Pacing and CRT2 and ESC HFA Guidelines on Acute and Chronic Heart Failure', but also to the technology which has become more widely available and more affordable. This is very good but the proportion of patients in NYHA II could most probably still increase and NYHA IV decrease in view of the long-term disease modifying effects of CRT leading to decreased mortality and HF related hospitalisations and the less efficacy of CRT for NYHA IV patients.

Even if the ratio of CRT-D devices increased in the last 8 years from one third to almost a half of the implanted CRT devices in Romania, these numbers are still lower than in the other European countries where CRT-Ds are implanted in more than $70 \%$ of cases. This might be partly explained by the fact that only $36.4 \%$ of the patients had ischemic cardiomyopathy in the Romanian cohort. Both dilated cardiomyopathy and ischemic heart disease patients with heart failure and with left ventricular ejection fraction below $35 \%$ despite 3 months of optimal medical treatment have a class I indication for ICD implantation in primary prevention I and CRT is indicated when ICD implantation is planned ${ }^{2}$. Even if half of the patients in this European cohort were implanted a CRT device due to heart failure with indication for ICD, this indication only accounted for $\mathbf{2 8 . 6 \%}$ of implantations in the Romanian group. There is a reasonable amount of data on the benefit of ICD implantation in patients with ischemic cardiomyopathy, but there is still controversy regarding whether CRT-D implantation has benefits compared with CRT-P in patients with non-ischemic dilated cardiomyopathy. The DANISH trial showed a decrease in sudden cardiac death incidence in CRT-D patients, but no over-all survival benefit over CRT-P10 except in a subgroup of patients below 70 years of age. Recent data has confirmed more favourable outcomes in ischemic cardiomyopathy patients implanted with a CRT-D versus CRT-P, but no survival benefit of CRT$D$ over CRT-P was observed in patients with non-ischemic dilated cardiomyopathy, with only $0.4 \%$ excess sudden cardiac death in CRT-P patients" ${ }^{\prime \prime}$.

Financial limitations also limit physician's options, probably contributing to CRT-P choice over CRT-D 
in some cases. This might be an important issue, especially given the fact that Romanian patients were younger but with more severe heart failure, more heart failure-related hospitalizations, larger ventricles, lower ejection fractions and wider QRS complexes. Besides device choice, economic factors limiting patients' access to radiofrequency ablation for atrial fibrillation or premature ventricular complexes also relevant costdriving interventions influence, in the end, the medical treatment. This could be one of the reasons why Romanian patients receive more often amiodarone. Another important difference in medical treatment observed in this survey was a more frequent use of MRA in Romania. As $84 \%$ of Romanian patients had an LVEF of less than $40 \%$, with an indication for MRA, the percentage of patients treated with MRA was higher than the one reported in QUALIFY survey'2, where $69 \%$ percent of patients were on MRA, mirroring the more advanced heart failure in Romanian cohort and an increased guideline adhesion most probably given the fact that Romanian implant centres are university hospitals.

Besides differences in device options, choice of implanted leads were also slightly different. Bipolar left ventricular leads were chosen in $80.1 \%$ of Romanian patients, while $57.8 \%$ of the other European patients received multipolar leads. The choice of the LV lead did not affect the QRS narrowing which was similar to the European total cohort. Moreover, it remains to be shown if multipolar leads are linked to better outcome.

Several procedural differences between Romanian and other European physicians are worth emphasizing. First, LV lead position was optimized based on EGM by Romanian physicians and on surface ECG in other European centres. Second, AV and VV delay programming were performed in Romanian patients before discharge significantly more often than in other European patients. Further data on outcome would be interesting on this matter.

One of the interesting finding of this survey was that, even if Predictors of Response to CRT (PROSPECT) ${ }^{13}$ and Echocardiography Guided Cardiac Resynchronization Therapy (EchoCRT) ${ }^{14}$ trials did not show any benefit of assessing mechanical dyssynchrony by echocardiography for CRT indication on top of conventional criteria, echocardiography was highly used in the Romanian group. Moreover, the ECHO-CRT study failed to show the value of mechanical dyssynchrony criteria for CRT response in patients with narrow QRS. In this study CRT in such patients was actually linked to wor- se survival. Despite of this scientific evidence mechanical dyssynchrony was amongst indications for CRT in $40.4 \%$ of Romanian patients, whereas this was taken into account for only $11.0 \%$ of implantations in the other European countries. One reason for difference may be the financial limitations in Romania which may have imposed a stricter patient selection than in other countries and echocardiographic criteria could contribute to this selection. Concerning imaging techniques in these patients, similar to other countries, cardiac MRI was rarely used in this heart failure cohort.

As expected, the patients had fairly wide QRS complexes, most frequently with left bundle branch block and the majority was in sinus rhythm. The small number of patients with atrial fibrillation in the Romanian group may also be due to financial limitations. Due to the class Ila indication for CRT in patients with permanent atrial fibrillation ${ }^{1,2}$, physicians may choose to direct resources towards patients with class I indications.

In comparison with the first CRT survey, a low number of off-label CRT implantations were observed in the Romanian group, with a small proportion of patients with narrow QRS complex, with left ventricular ejection fraction above $35 \%$ and no patient in NYHA functional class'.

The complications incidence was higher in Romanian cohort. Several factors could contribute to this. First, as many implant centres from Romania were included in this survey, this reflects the fact that some centres are still on the learning curve. Second, $32 \%$ of patients were anticoagulated, and the higher incidence of bleeding complications arises from a still common practice of anticoagulation bridging. The results from the CRT Survey II may initiate a discussion and action plan on how to bring down the complication rates.

\section{STUDY LIMITATIONS}

This survey has several limitations. No standardized method was used for assessing left ventricular ejection fraction, which has an important impact on CRT decision. Also, there is no available data whether a defibrillator was indicated as primary or secondary prevention of sudden cardiac death. Further data would be needed in order to understand the actual CRT-D patient profile in different European countries.

\section{CONCLUSIONS}

Romanian heart failure patients are more symptomatic and have worse outcome features, such as a lower left 
ventricular ejection and wide QRS complexes. Indications regarding CRT implantation follow the most recent ESC guidelines, but the ratio of CRT-D devices in Romania is lower than in the other European countries. More data is needed in order to understand the underlying causes for our findings.

\section{Conflict of interest: None declared.}

\section{References}

I. Ponikowski P, Voors AA, Anker SD, Bueno H, Cleland JG, Coats AJ, Falk V, Gonzalez-Juanatey JR, Harjola VP, Jankowska EA, Jessup M, Linde C, Nihoyannopoulos P, Parissis JT, Pieske B, Riley JP, Rosano GM, Ruilope LM, Ruschitzka F, Rutten FH, van der Meer P AFM. 2016 ESC Guidelines for the diagnosis and treatment of acute and chronic heart failure. Eur Hear J 2016;37(27):2129-2200.

2. Brignole M, Auricchio A, Baron-Esquivias G, Bordachar P, Boriani G, Breithardt O, Cleland J, Deharo JC, Delgado V, Elliott PM, Gorenek B, Israel CW, Leclercq C, Linde C, Mont L, Padeletti L, Sutton R, Vardas PE. 2013 Guidelines for cardiac pacing and cardiac resynchronization therapy. Eur Heart J 2013;34(29):228I-2329.

3. Dickstein K, Normand C, Anker SD, Auricchio A, Blomström-Lundqvisit C, Bogale N, Cleland J, Filippatos G, Gasparini M, Gitt A, Hindricks G, Kuck KH, Ponikowski P, Stellbrink C, Ruschitzka F, Linde C. European Cardiac Resynchronization Therapy Survey II: rationale and design. EP Europace 20I5;I7(I):|37-|4I.

4. Dickstein K, Bogale N, Priori S, Auricchio A, Cleland JG, Gitt A, Limbourg T, Linde C, Veldhuisen DJ, Brugada J. The European cardiac resynchronization therapy survey. Eur Heart J 2009;(30):2450-2460

5. Linde C, Abraham WT, Gold MR, St John Sutton M, Ghio S, Daubert C; REVERSE Study Group. Randomized Trial of Cardiac Resynchronization in Mildly Symptomatic Heart Failure Patients and in Asymptomatic Patients With Left Ventricular Dysfunction and Previous Heart Failure Symptoms. J Am Coll Cardiol 2008;52(23):I834-I843

6. Moss AJ, Hall WJ, Cannom DS, Klein H, Brown MW, Daubert JP, Estes NA 3rd, Foster E, Greenberg H, Higgins SL, Pfeffer MA, Solomon
SD, Wilber D, Zareba W; MADIT-CRT Trial Investigators. Cardiac-resynchronization Therapy for the Prevention of Heart-Failure Events. N Engl ] Med. 2009;36 I (14):| 329-|338.

7. Tang ASL, Wells GA, Talajic M, Malcolm OA, Sheldon R, Connolly S, Hohnloser SH, Nichol G, Birnie DH, Sapp JL, Yee R, Healey JS, Rouleau JL. Cardiac-Resynchronization Therapy for Mild-to-Moderate Heart Failure. N Engl J Med 2010;363(25):2385-2395.

8. Brugada J, Vardas P, Wolpert C. The EHRA White Book 2009 The Current Status of Cardiac Electrophysiology 2009.

9. Hindricks G, Camm J, Merkely B, Raatikainen P, Arnar DO. The EHRA White Book 2017 The Current Status of Cardiac Electrophysiology 2017.

10. Køber L, Thune JJ, Nielsen JC, Haarbo J, Videbæk L, Korup E, Jensen $G$, Hildebrandt $P$, Steffensen FH, Bruun NE, Eiskjær $H$, Brandes A, Thøgersen AM, Gustafsson F, Egstrup K, Videbæk R, Hassager C, Svendsen JH, Høfsten DE, Torp-Pedersen C, Pehrson S. Defibrillator Implantation in Patients with Nonischemic Systolic Heart Failure. N Engl J Med 2016;375(I3): I22I-I230.

II. Barra S, Boveda S, Providência R, Sadoul N, Duehmke R, Reitan C, Borgquist R, Narayanan K, Hidden-Lucet F, Klug D, Defaye P, Gras D, Anselme F, Leclercq C, Hermida JS, Deharo JC, Looi KL, Chow AW, Virdee M, Fynn S, Le Heuzey JY, Marijon E, Agarwal S. Adding Defibrillation Therapy to Cardiac Resynchronization on the Basis of the Myocardial Substrate. J Am Coll Cardiol 2017;69(13):1669-1678.

12. Komajda M, Anker SD, Cowie MR, Filippatos GS, Mengelle B, Ponikowski P, Tavazzi L. Physicians' adherence to guideline-recommended medications in heart failure with reduced ejection fraction: data from the QUALIFY global survey. Eur J Heart Fail 2016;18(5):5।4522.

13. Chung ES, Leon AR, Tavazzi L, Sun JP, Nihoyannopoulos P, Merlino J, Abraham WT, Ghio S, Leclercq C, Bax JJ, Yu CM, Gorcsan J 3rd, St John Sutton M, De Sutter J, Murillo J. Results of the Predictors of Response to CRT ( PROSPECT ) Trial. Circulation 2008; I 17:26082617.

14. Ruschitzka F, Abraham WT, Singh JP, Bax JJ, Borer JS, Brugada J, Dickstein K, Ford I, Gorcsan J 3rd, Gras D, Krum H, Sogaard P, Holzmeister J. Cardiac-Resynchronization Therapy in Heart Failure with a Narrow QRS Complex. N Engl J Med 2013;369(I5): I3951405. 